\title{
Curious Remission/Slight and Temporary Recoveries from Malaria Validate Germ Terrain Duality (Gtd) Theory
}

\author{
Mister Seun Ayoade* \\ University of Ibadan, Nigeria
}

Submission: August 11, 2017; Published: August 15, 2017

*Corresponding author: Mister Seun Ayoade, University of Ibadan, Nigeria, Email: seunoodua@yahoo.com

\section{Opinion}

There is more to malaria than meets the eye; or rather, more to malaria than is contained in the official narrative contained in nursing and medical textbooks. In a sufferer who survives an untreated infection the fever ultimately subsides, to be followed by occasional relapses as in the case of plasmodium vivid infections. The disease is, however much less persistent and even if not eradicated by drug treatment is eventually self curing. Black water fever or haemoglobin uric fever used to be a common and much dreaded complication of plasmodium falciparum infection, occurring almost exclusively in people without acquired immunity, exposed to repeated infection. In response to some uncertain stimulus large numbers of red cells disrupt simultaneously, liberating their haemoglobin, which reaches the urine and gives it the typical black appearance. The resultant anemia is extremely sudden and severe, mortality is high, recovery is slow and complete rest from the moment of the attack is the only universally accepted treatment' [1].

In West Africa, it is not unheard of for people to feel early onset symptoms of malaria, subsequently take a break from work and have a rest/sleep (especially in a cool environment) and awake, many hours later completely symptomless!

What is the scientific explanation for this peculiar, yet nevertheless generally known phenomenon? The Germ-Terrain duality theory of disease states that the etiology of certain diseases/diseased states is better explained as a complex interplay between germs and the inherent anatomical/ physiological integrity of the body cells [2-4].

It argues that the etiology of certain diseases is not fully explained merely by the presence of germs (Germ Theory) or by a mere loss of cellular integrity (Terrain Theory) [2-4]. As a result the prevention and treatment of such diseases should focus not just on fighting germs but on maintaining/restoring the anatomical/physiological cellular integrity. The GermTerrain duality (GTD) theory is a harmonization of the current
Germ Theory (popularized by Louis Pasteur) and the hitherto discarded Terrain Theory (popularized by Pierre Bechamp). The blood's Acid -base balance is affected by physical stress/strain and heat [5-7].

The acid-base balance of the blood simply means the balance between the amount of carbonic acid and bicarbonate in the blood [8]. This balance must be maintained at a constant ratio of $1: 20$ so that the blood plasma ph is kept at 7.4.

It is no accident that in the olden days before malaria was eradicated in Europe the worst outbreaks occurred in the hot summer viz- 'In England it (malaria) flourished during the summer along the Thames valley, until the building of the Thames embankment cleared the swamps of London. James the First and Lord Protector Oliver Cromwell are supposed to have died of it (malaria). The intensity of endemicity in any area depends firstly on climate. In subtropical and temperate zones transmission is interrupted by the cold season'[1].

Physical Stress causes acidosis (reduces blood ph). In such acidic conditions plasmodium thrives. Plasmodium has an acidic compartment within it, and its digestive vacuole is acidic [8]. Removal of heat/physical strain/stress raises ph, adversely effecting/killing plasmodium. Plasmodium feeds/scavenges/ forages on dead cells and as a byproduct of this feeding process people get malaria. The parasite feeds at the expense of the red cell, depositing in its body a characteristic pigment representing the residue [1].

Removal of stress starves plasmodium of its food source $[2,3]$ hence plasmodium dies, or reverts to an innocuous form/shape (pleomorphism). Pleomorphism is defined as the condition in which an individual assumes a number of different forms, e.g. during its life cycle. 'The malarial parasite (plasmodium) displays pleomorphism' [7].

Once the numbers of malaria parasites falls below a certain number, symptoms disappear viz-The severity of attacks of 
malaria depends largely upon the number of parasites present. The minimum number capable of producing clinical symptoms of malaria is fifty per cubic millimeter of blood (equivalent to 150 million parasites in a man weighing ten stone, which is 63.5 kilograms). The maximum density of parasites varies with the species of plasmodium; in quartan malaria it rarely exceeds 10,000 , in benign tertian 50,000, while in malignant tertian, it is practically unlimited, but the prognosis is grave if the density attains 500,000' [1].

Hence if Mr. A has 50 malaria parasites (plasmodium) in a cubic millimeter of his blood as he slaves away under the sun he begins to feel sickly. Mr A informs his boss. His boss gives him permission to rest and Mr. A retires to the sick bay. There Mr A drinks some cold water and lies down under a cooling fan. Starved of dead cells to feed on (since the cessation of harsh labor has reduced the rate of Mr A's cell death) some plasmodium die. The removal of the heat from the sun also reduces the number of cells dying due to that cause. Plus, the increased ph stops/begins to reverse Mr A's acidosis. In an alkaline environment many other plasmodium die. Six hours later Mr. A wakes up feeling much better and free from malaria (for the time being at least). The plasmodium count per cubic millimeter of Mr A's blood has gone down from 50 to 35! This is the scientific explanation for those curious, drugless remissions from the early onset symptoms of malaria fever.

Such drugless remissions/recoveries validate the Germ Terrain Duality theory because they suggest that germs are scavengers of dead tissue and waste, are affected by $\mathrm{pH}$ and that the presence of germs alone does not give the full picture and cannot solely account for the etiology of malaria fever. The anatomical and physiological terrain of the blood and body cells also played a major role.

Clinical Implications- I suggest (especially in the light of the blossoming field of nanotechnology) that malaria immune boosters [not to be confused with mere prophylactics like daraprim] be created so that plasmodium never multiplies to the number to which it can cause symptoms.

\section{Referances}

1. (1970) Chambers's Encyclopaedia, International Learning Systems London, England.

2. Ayoade S (2017) Germ-terrain duality of sickness, equivalent of waveparticle duality of light for the biological sciences? Bechamp revisited. Int J AnatVar 10(1): 10-11.

3. Ayoade S (2017) Etiology, Epidemiology and Therapeutic history of malaria validate germ-terrain duality; Postulates Thereof. J Mol Genet Med 11: 261.

4. Ayoade S (2017) Thalassemias validate germ terrain duality of malaria. Health Sci J 11: 3.

5. Robergs RA, Ghiasvand F, Parker D (2004) Biochemistry of exerciseinduced metabolic acidosis. Am J Physiol Regul Integr Comp Physiol 287(3): R502-R516.

6. Toth HL, Greenbaum LA (2003) Severe acidosis caused by starvation and stress. Am J Kidney Dis 42(5): E19-E19.

7. (2003) Oxford mini Dictionary for Nurses, $\left(5^{\text {th }}\right.$ edn), Oxford University Press, India.

8. Yayon A, Cabantchik ZI, Ginsburg H (1984) Identification of the acidic compartment of Plasmodium falciparum-infected human erythrocytes as the target of the antimalarial drug chloroquine. EMBO J 3(11): 26952700

\section{Your next submission with Juniper Publishers} will reach you the below assets

- Quality Editorial service

- Swift Peer Review

- Reprints availability

- E-prints Service

- Manuscript Podcast for convenient understanding

- Global attainment for your research

- Manuscript accessibility in different formats

( Pdf, E-pub, Full Text, Audio)

- Unceasing customer service

Track the below URL for one-step submission https://juniperpublishers.com/online-submission.php 